\title{
Impact of Information and Communication Technologies on the Psychoanalytic Psychotherapeutic Technique
}

\author{
Luan Paris Feijó ${ }^{*}, 1$ \\ Orcid.org/0000-0002-7587-3987 \\ Nathália Bohn Silva ${ }^{1}$ \\ Orcid.org/0000-0002-0384-7579 \\ Silvia Pereira da Cruz Benetti ${ }^{1}$ \\ Orcid.org/0000-0001-8557-2216
}

${ }^{1}$ Universidade do Vale do Rio dos Sinos, São Leopoldo, RS, Brasil

\begin{abstract}
Information and Communication Technologies (ICTs) have penetrated various contexts, including clinics that provide face-to-face psychotherapy services. From this perspective, the use of these resources impacts on technical concepts of psychoanalytic psychotherapy. Therefore, the aim of this study was to understand how psychodynamic psychotherapists perceive the impacts of ICTs on the face-to-face psychoanalytic technique. A qualitative and exploratory study was carried out with 11 psychologists, specialized in psychoanalytic psychotherapy. They responded to a semi-structured interview and completed a sociodemographic data sheet. The data were analyzed through thematic analysis. The results evidenced impacts related to the therapeutic alliance, neutrality, psychotherapeutic setting, and transference, indicating that the use may provide different comprehensions of the therapeutic relationship and the psychic functioning of the patient. The study contributes as an aid for professionals to manage ICTs in psychotherapy and encourages reflection on how best to combine technology with face-to-face clinical practice. It is important to investigate the experiences of psychotherapists and their academic training to broaden the discussions on the subject.
\end{abstract}

Keywords: Clinical Psychology, Psychodynamic Psychotherapy, social media and social networks.

\section{Impacto das Tecnologias de Informação e Comunicação na Técnica Psicoterápica Psicanalítica}

\section{Resumo}

As Tecnologias de Informação e Comunicação (TICs) têm ingressado em diversos contextos, entre eles, os consultórios que oferecem serviço psicoterápico presencial. Nessa perspectiva, o uso desses recursos impacta em conceitos técnicos da psicoterapia psicanalítica. Portanto, o objetivo deste estudo foi o de compreender como os psicoterapeutas de abordagem psicodinâmica percebem os impactos na técnica

* Mailing address: Universidade do Vale do Rio dos Sinos, Av. Unisinos, 950, Cristo Rei, São Leopoldo, RS, Brazil 93022-750. Phone: (51) 99180-1619. E-mail: lparisf@gmail.com

Financial support: To the Coordination of Improvement of Higher Level Personnel for the granting of financial assistance, in the form of a master's degree, to enable this research. 
psicoterápica psicanalítica presencial. Foi realizada uma pesquisa qualitativa e exploratória com 11 psicólogos que tinham especialização em psicoterapia de orientação psicanalítica. Eles responderam à entrevista semiestruturada e a uma ficha de dados sociodemográficos. Os dados foram analisados por meio de análise temática. Os resultados evidenciaram impactos relacionados à aliança terapêutica, à neutralidade, ao setting psicoterápico e à transferência, indicando que a utilização pode proporcionar diferentes compreensões da relação terapêutica e da dinâmica de funcionamento psíquico do paciente. O estudo contribuiu para auxiliar os profissionais no manejo das TICs em psicoterapia e para fomentar a reflexão sobre a melhor forma de conjugar a tecnologia com a prática clínica presencial. Torna-se importante investigar as vivências dos psicoterapeutas e a sua formação acadêmica para ampliação das discussões sobre a temática.

Palavras-chave: Psicologia Clínica, Psicoterapia Psicodinâmica, mídias sociais e redes sociais.

\section{Impacto de las Tecnologías de Información y Comunicación en la Técnica Psicoterápica Psicoanalítica}

\section{Resumen}

Las Tecnologías de Información y Comunicación (TICs) han entrado en diversos contextos, entre ellos, los consultorios que ofrecen servicio psicoterápico presencial. En esa perspectiva, el uso de esos recursos impacta en conceptos técnicos de la psicoterapia psicoanalítica. Por lo tanto, el objetivo de este estudio fue el de comprender cómo los psicoterapeutas de abordaje psicodinámico perciben los impactos en la técnica psicoterápica psicoanalítica presencial. Se realizó una investigación cualitativa y exploratoria con 11 psicólogos que tenían especialización en psicoterapia de orientación psicoanalítica. Respondieron a la entrevista semiestructurada ya una ficha de datos sociodemográficos. Los datos se analizaron mediante análisis temáticos. Los resultados evidenciaron impactos relacionados a la alianza terapéutica, a la neutralidad, al ajuste psicoterápico ya la transferencia, indicando que la utilización puede proporcionar diferentes comprensiones de la relación terapéutica y de la dinámica de funcionamiento psíquico del paciente. El estudio contribuyó a auxiliar a los profesionales en el manejo de las TICs en psicoterapia y para fomentar la reflexión sobre la mejor forma de conjugar la tecnología con la práctica clínica presencial. Es importante investigar las vivencias de los psicoterapeutas y su formación académica para ampliar las discusiones sobre la temática.

Palabras clave: Psicología Clínica, Psicoterapia Psicodinámica, medios de comunicación sociales, red social.

It is estimated that 85.6 million Brazilians, $49.4 \%$ of the population, use the Internet through microcomputers, mobile phones, tablets and other technological resources. Based on this, a panorama is presented in which the information and communication technological resources (ICTs) are increasingly present in Brazilian society (Hallberg, \& Lisboa, 2016; Instituto Brasileiro de Geografia e Estatística [IBGE], 2013).

WhatsApp, Messenger, Telegram, Facebook and other technological forms of communication and information are accessed through the Internet. These tools allow the exchange of virtual communications between two or more people, aiming to produce, manipulate and share information (Barcellos et al., 2015; Distéfano, Mongelo, O'Conor, \& Lamas, 2015).

In addition to their use in daily life, these forms of communication may also arise in the clinical context of psychotherapy (Zilberstein, 2015). Psychotherapy is the professional practice performed by psychologists, who use systematic methods and scientifically recognized techniques to analyze and understand individuals or groups, in a confidential and ethical way (Conselho Federal de Psicologia [CFP], 2012). 
Because they are also present in the psychotherapeutic context, Gabbard, Kassaw, and Perez-Garcia (2011) suggest that health professionals may have mechanisms that preserve their professional identity, in order not to compromise the psychotherapeutic work. In addition, they recommend that training institutions teach students about the boundaries in the therapist and patient relationship and the ethical issues related to technology. However, the recommendations focus on the protection of the therapist, allowing space for discussion regarding the impacts of technological resources on the technique and psychotherapeutic process, especially in the psychodynamic approach. In general, psychotherapists of this theory adopt less focal and more interpretive interventions in a face-to-face relationship (Hallberg, \& Lisboa, 2016).

The national and international literature presents a series of articles relating psychotherapy and technological resources (ICTs). Many of these studies are focused on distance psychotherapy (Pieta, \& Gomes, 2014; Pieta, Siegmund, Gomes, \& Gauer, 2015). The majority of the studies were performed in the United States, where online therapies are recognized and accepted (Crestana, 2015). In addition, studies relating ICTs with psychotherapy are also about distance training and supervision, with few being about the technique in the face-to-face context (Barnett, 2011).

The articles that discuss ICTs as technological resources in face-to-face psychotherapy, mainly in South America, are scarce or not indexed in the digital databases (Pires, 2015). However, several authors suggest studies on the use and management of technological resources in face-to-face psychotherapy as a possibility that needs to be better understood for the improvement of the psychotherapeutic technique, since there is little clinical evidence on the subject (Barcellos et al., 2015; Hallberg, \& Lisboa, 2016; Neves, \& Silva, 2014; Pires, 2015).

Studies show that the use of communication and information technological resources, such as sending text messages/WhatsApp, could increase adherence to treatment and favor the therapeutic alliance (Bunge, López, Mandil, Go- mar, \& Borgialli, 2009; Distéfano et al., 2015). The therapeutic alliance is a factor common to psychotherapeutic approaches, composed of an agreement regarding the goals and the tasks of the treatment, as well as the establishment of a positive bond of trust and attachment between the therapist and patient that makes the psychotherapeutic work possible (Oliveira, \& Benetti, 2015). However, the challenges to the increment of this exercise - ICTs in the practice, would be related to fears and rejections of the users, as well as the possible interference in the relationship with the therapist (Miró, 2007).

Although the studies of Bunge et al. (2009) and of Distéfano et al. (2015) discuss technological resources in psychotherapy more comprehensively, the study by Barcellos et al. (2015) specifies the use for the psychoanalytic psychotherapeutic technique. For the authors, the new forms of communication become extra-setting situations that, in many cases, are not included in the rules and in the contract established between the pair. Communication through technological resources could express communicative actions, as well as actings and resistances. Thus, these situations would need to be worked on in the face-to-face relationship with the patient (Barcellos et al., 2015; Sfoggia et al., 2014).

From this perspective, psychodynamic psychotherapy focuses on Freud's recommendations that are based on the free association of content in the patient's mind, on the neutrality and on the anonymity of the psychotherapist. The therapist's task would be to make the unconscious conscious through the psychoanalytic interventions (Gabbard, 2015). With this, the conflicts of the person analyzed/patient could be re-signified, making it possible for them to be elaborated. For this, the pair would establish rules that will guide the analytical work and favor the establishment of a transference neurosis in the therapeutic setting (Freud, 1912/1996a; Zimerman, 1999). However, regarding the inclusion of social media in the psychotherapeutic context, the psychoanalytic literature discusses the use cautiously, since these devices end up influencing the notion of technical rules, setting (Crestana, 2015; Luz, 2015; Stadter, 2013), neu- 
tralidade (Kowacs, 2014; Sfoggia et al., 2014), transference (Barbosa et al., 2013; Kowacs, 2014) and the therapeutic alliance (Distéfano et al., 2015).

Although the topic has been discussed for some time, there seems to be no consensus among practitioners of the psychoanalytic psychotherapeutic approach on how to use and manage ICTs in face-to-face relationships (Barcellos et al., 2015; Crestana, 2015). There is still a lack of studies involving this approach, compared to other approaches such as Behavioral Cognitive Therapy (Hallberg, 2015; Machado et al., 2016); In addition, there is little discussion about the use of clinical material or the possibilities and limits of technological resources in psychoanalysis (Barcellos et al., 2015; Crestana, 2015; Machado et al., 2016). Therefore, this article aims to comprehend how psychodynamic psychotherapists perceive the impact on the face-to-face psychoanalytic psychotherapeutic technique in relation to the use of the information and communication technological resources with their patients.

\section{Method}

\section{Design}

The present study was based on a qualitative (Breakwell, Hammond, Five-Schaw, \& Smith, 2010) and exploratory approach (Gerhardt \& Silveira, 2009). In order to qualify the methodological procedure of the present study, the Consolidated Criteria for Reporting Qualitative Research (COREQ) checklist was used aiming to present a detailed report of the data (Tong, Sainsbury, \& Craig, 2007). The criteria of the instrument are arranged in 32 items and divided into three domains, with the first referring to the research team, the second to the design of the study and the third to the analysis and conclusions (Tong et al., 2007).

\section{Participants}

Eleven psychologists, ten female and one male, participated, all of whom had postgraduate training in psychoanalytic psychotherapy. It should be noted that the selected participants concluded their training in psychodynamic psy- chotherapy in different training centers in the metropolitan region of the city of Porto Alegre in Rio Grande do Sul state. This procedure was adopted with the aim of selecting a sample that, although having studied the same theoretical approach, had discussed the psychoanalytic concepts from different perspectives and carried out supervision with different professors. In addition, the criterion of data saturation (Fontanella, Ricas, \& Turato, 2008) was used for the final number of participants, thus, when it was noticed that the information emitted by the participants did not present new contents, the interviews were terminated.

\section{Instruments}

The instruments used for the data collection were: (1) sociodemographic data form and (2) semi-structured interview with guiding questions. The semi-structured interview was developed from a pilot study conducted with six psychologists who had postgraduate training in psychoanalytic psychotherapy. These professionals answered a first version of the questionnaire with 19 open questions. After analyzing the answers, a new version of the questionnaire was developed with nine open questions distributed in four categories and additional exploratory topics. The exploratory themes and questions were centered on the inclusion of technological resources in the clinical practice, the penetration of these resources into the psychoanalytic technique, the training of professionals and the management of clinical cases through technological resources.

\section{Data Collection Procedures}

The study participants were contacted via telephone or e-mail. After agreeing to participate, a day and time was scheduled with the professional to carry out the interview. The participants signed two copies of the consent form. After this procedure, the audio recorded interviews were carried out. First, the sociodemographic data sheet was completed and the semi-structured interview was subsequently performed. The interviews had an average duration of 35 minutes. 


\section{Ethical Procedures}

The study followed Resolution 510/2016 (2016) of the National Health Council, an organ of the Ministry of Health and was approved by the Universidade do Vale do Rio dos Sinos (Unisinos) Ethics Committee (CAE: 60157816.8.0000.5344), under authorization No. 1.790 .149 .

\section{Data Analysis Procedures}

The data were analyzed through realistic thematic analysis, which is understood as an analysis of the predominant themes of the interviews and that operates with the reality of the participants (Braun, \& Clarke, 2006).

Initially, the audio recordings of the interviews were transcribed. After transcription, the material was read in a free way to become more familiar with the data collected. In a second reading, the thematic units emerged. In the third reading, the thematic units were grouped, which generated the themes of the study. Finally, the communications were divided and organized into themes. The interviews were analyzed and categorized by two independent judges. In cases where there was disagreement, a third judge was asked to categorize the materials. Thus, consensus among the judges was adopted for the solution of conflicting cases.

The communications were gathered in themes, these being: (1) experience of the professionals in the use of information and communication technologies in the psychodynamic psychotherapy practice; (2) impacts of information and communication technologies on the psychoanalytic technique and (3) training of the professionals to manage technological resources in the practice.

In this article, the results of the theme (2) impacts of information and communication technologies on the psychoanalytic technique will be presented, which was divided into the following categories: (a) therapeutic alliance; (b) neutrality; (c) setting and (d) transference. In order to elucidate the impacts on the technique, the interviews will be presented. The other themes,
(1) experience of the professionals in the use of information and communication technologies in the psychodynamic psychotherapy practice, and (3) training of the professionals to manage technological resources in the practice, will be discussed in another article prepared by the authors.

\section{Results}

The therapists had a mean length of clinical experience of 10.18 years ( $s d=5.30$ years), with a mean of 10.55 years ( $s d=5.20$ years) since they completed the undergraduate course and 6.46 years ( $s d=3.36$ years) since the specialization. Their ages ranged between 27 and 55 years ( $m=34.7$ years and $s d=7.37$ years). In addition to all having the qualification of specialist in psychoanalytic psychotherapy, three of the participants had completed their master's degree in clinical psychology, in research groups with a focus on the psychoanalytic approach. Of these three participants, two were teachers of training institutions in psychoanalytic psychotherapy in Rio Grande do Sul.

Regarding the use of information and communication technology resources, all the participants used WhatsApp in their clinical practice. Three of the psychotherapists were contacted by Messenger and nine through Facebook. None of them used Instagram or other forms of information and communication technologies.

From the data analysis, the reports were grouped into thematic units and later the categories of thematic analysis were generated. These aspects were identified in the following categories: (a) therapeutic alliance; (b) neutrality; (c) therapeutic setting and (d) transference. Thus, the thematic units represent the grouping of the interviews and relate the impacts on the psychoanalytic psychotherapeutic technique.

\section{Therapeutic Alliance}

The first category, (a) therapeutic alliance, presented thematic results related to adherence to the treatment and identification of the psychic weaknesses of the patient, as shown in Table 1 . 
Table 1

Impact on the Therapeutic Alliance

Impact

Vignette

Adherence to treatment

"I think when you show that you are more available to some patients, they tend to bond faster" (Participant 3).

Identification of the psychic

... So, for example, [when the patient says] you took time to respond to me, weaknesses of the patient I saw that you looked at WhatsApp and you did not answer me . . . [therapist analyzes] In this way, the weakness of the patients will appear, often at that moment. (Participant 5)

In this category, the participants reported that technological resources impact on the therapeutic alliance in different ways. The impacts perceived as positive in the use of ICTs were when the patients felt they were welcomed, they adhered better to the treatment and they felt their psychotherapist to be more empathetic, due to being available through social media.

In addition, the technologies helped the therapists understand the psychic weaknesses of the patient, for example, whether the client needed the therapist to gratify him/her by responding to the messages or it frustrated him/her due to viewing it and leaving the situation to be worked on in the session. In this sense, it was understood

Table 2

Impacts on Neutrality that whether the therapist intervened more actively or not through the information and communication technologies, it could impact on the therapeutic alliance, with this influencing the patient's decision to maintain the treatment or not. Therefore, the professional management varied according to the needs that the therapist thought were important for the treatment.

\section{Neutrality}

The second category (b) neutrality presented thematic results centered on the concern with the position of the participating psychotherapists faced with the ICTs; the personal exposure and the perception of the neutrality in the present day. Table 2 summarizes the results found.

Impact

Vignette

Positioning adhered to by psychotherapists

Exposure of the Therapist

Perception of neutrality in the present day
... I always think of WhatsApp, because Facebook is a concern that I have of being [exposed], we post ideas, I try to post as few ideas as possible about my ideologies or anything, because I use it more as a reflection. (Participant 2)

Their main [concern] . . . how are you going to write a message? I take great care when I am going to write a text message so I don't use slang, don't use abbreviations. For example, when I write "o que (what)", I do not just put "oq", I write the Portuguese correctly. (Participant 10)

WhatsApp I never had a picture of me, it's a tree, because from there I know the patient accesses it, the idea of the patient seeing a picture of me happy, or more beautiful, or with a baby, or with a little dog ... moments, ah the patient is alone and sees the picture of a happy couple there, you know? I think it must be difficult. (Participant 8)

"... You can see the time the therapist entered, the photo he used in the profile" (Participant 6). ... a situation with an adolescent occurred. He found my profile [Facebook] and could see the pages I had liked, I did not know that I could close it until then, and he asked me [in the session] why I had liked that page. (Participant 1)

... although this [neutrality] in the present day is somewhat illusory because nothing else is completely neutral, people have access to our lives in different ways, through what we publish through our [professional] training. (Participant 7) 
Regarding the neutrality theme, the participants considered that the positioning of the psychotherapists relative to the technological resources could negatively impact the treatment, because WhatsApp shows the time at which they viewed their conversations. Facebook shows the subjects that have been commented on or shared, in addition to having images available on the network, if the privacy setting has not been configured. Another situation that raised questions, was related to the way the professional appears in these communicative channels, for example, when the therapist writes a message or publishes positions on the social networks. These occurrences can reveal information about the psychotherapist's private life beyond his or her professional practice.

Also related to neutrality, participant 6 reported the example in which a depressed patient who viewed a happy photo of the therapist on Facebook projected hostile feelings due to not being able, at least momentarily, to have the same feelings as the therapist. Finally, in the interviews the psychotherapists reported that with information and communication technologies, personal information has become faster and easier to find in the various technological resources.

\section{Therapeutic Setting}

In this category, the impacts perceived by the therapists are related to the agreements in the therapeutic work contract, to the technological resources as a third party in the therapeutic setting and to the extra-setting situations, understood as those that appear externally to the faceto-face session. Through the interview reports, Table 3 exemplifies these impacts.

Table 3

Impacts on the Therapeutic Setting

Impact Vignette

Maintenance of the Therapeutic Contract

Extra-setting Situations
But much more for that thing of ... um ... to schedule ... to cancel ... the patient: I need to cancel the consultation today. Can you change it? I need an extra session. [More] in that sense than anything else. (Participant 4)

". . . That starts [ICTs] to be a problem ... when contents that should be dealt with in the session appear outside" (Participant 5).

"I think a lot of things can be solved there in WhatsApp and do not go into the setting. .. I think solving things through WhatsApp often lets us talk about it more deeply in the session" (Participant 9).

... [I] get messages from perverse or borderline patients, I need to be more careful with these, because they do not know how to use these technologies and end up putting the therapeutic process at risk ... they end up invading more, knowing the limit less, you know? So, the time is not convenient, um, they keep sending you a messages, right, to see if you really looked. (Participant 6)

I'm wondering how I can manage this . . especially when they are going to describe a Technological resources as a third party in the therapeutic setting situation, for example if they ask to read the WhatsApp conversation. Sometimes they explain a conversation so much, I do not know, with a boyfriend and instead of saying: "Ah, this, this and this happened..." they say "no, no, calm down there I'll read it to you so I don't forget anything". (Participant 10)
In this category, the psychotherapists participating in the study reported that their patients tended to request additional sessions, reschedule and cancel consultations through WhatsApp, rather than face-to-face. Participant 4 further reported that it would be necessary for the initial therapeutic contract itself to include agreements on how such information and communication technologies could be used, in order to establish a framework for them.

As far as extra-setting situations are concerned, the reports indicated that the therapists 
need to pay attention so that the communications that should occur in the session are not solved through the use of technological resources, since they would no longer be analyzed in depth. Examples of extra-setting situations provided by the psychotherapists were related to the performances, resistances, faults, remarks and contents that only emerge in the ICTs, but not in the sessions and, finally, the care in these situations with borderline patients.

Furthermore, on the subject of technological resources as a third party in the therapeutic setting, the participants highlighted that the new information and communication tools end up being another element of the face-to-face psycho- therapeutic setting, as the patient used WhatsApp and Facebook to report situations that occurred in their daily lives, interrupting a freely associated report. Within this same theme, another imminent problem was related to the clients of the participants using the ICTs within the session to look at the time, answer calls or send messages.

\section{Transference}

The transference category presented two topics of discussion by the participants, one related to the expression of the desires of the patients through means of the information and communication technological resources and the other related to the presence of transference.

Table 4

Impacts on Transference

Impact Vignette

Technological resources as representatives of the patients' desires

Manifestation of transference in the information and communication technological resources
When I was online at night or at some point she [patient] wanted to talk . . it was necessary to work with this in the session various times... that we had to make better use, to come more, to increase the frequency [of the consultations] . . ( Participant 2)

I think initially that the work of transference, which is something that is one of the pillars, as the patient will relive situations, we can use the tools [WhatsApp] to understand the need for a very present mother, or a very invasive mother, or a child suddenly asking this mother or father a lot depending on the function the patient projects . . . being able to use this within the session, use these examples that occur to be able to foment ideas, to interpret . . . (Participant 2)
In the first theme, technological resources as representative of the desires of the patients, the psychotherapists presented reports that their patients signaled their needs through these forms of communication and information. In this channel of communication, patients could express their anguish and therapists could either welcome it or abstain and subsequently discuss it in the session.

In the second theme, manifestation of transference through the information and communication technological resources, 10 of the 11 therapists believed that the technology was a conduit conducive for the occurrence of this. Only one participant believed that the transference would only take place in a face-to-face relationship and not through the technologies. The report present- ed in Table 4 shows a case in which recurrent requests to the psychotherapist could be understood as the manifestation of the transference, and not only as indiscriminate use by patient.

\section{Discussion}

From the participants' report, there has been a perceptible change in the psychoanalytic technique with the inclusion of information and communication technologies in the clinical practice. Although the psychotherapists presented a lot of clinical experience and professional training, it is possible to perceive that the management of these resources is cautious and directed toward combinations related to the psychotherapeutic work contract. However, the ICTs have 
presented a fertile field for the expansion and manifestation of transferential contents (Barbosa et al., 2013), resistances, acting out, extra-setting situations (Barcellos et al., 2015), complexities of the therapeutic setting itself (Luz, 2015) and for the therapeutic alliance (Bunge et al., 2009).

Psychoanalytic psychotherapy is primarily based on Freudian work regarding the free association of unconsciously arising contents in the mind of the person analyzed (Freud, 1912/1996a), as well as the effort of the psychotherapist for the patient to maintain a transference neurosis (Freud 1914/1996b, 1920/1996d). From this premise, it can be understood that if there are unconscious contents, which are governed neither by rules nor by time and can manifest themselves in different ways, it is then reflected that one of their manifestations could be from the information and communication technologies (Kowacs, 2014), thereby evidencing the needs, fragilities and frustrations of the patients, as well as their psychic functioning. The development of the psyche is modified by cultural transformations and, if we are part of a technological culture, we must not deny the inclusion of ICTs in the life of the patients (Kowacs, 2014), with the psychoanalysis needing to adapt to the new times without, however, losing its own characteristics (Kowacs, 2014).

With regard to the results of this study on the therapeutic alliance theme, the themes present were adherence to the treatment and identification of the psychic weaknesses of the patient. The literature indicates that technological resources can favor the adherence to psychotherapy and the connection with the therapist (Bunge et al., 2009). In this study, the perception of the participating professionals was that ICTs strengthened the therapeutic alliance (TA) and adherence to the treatment, as they favor the establishment of a feeling of acceptance by the therapist on behalf of the patient. Therefore, the results found are in agreement with the literature.

In addition to ICTs strengthening the TA, no evidence was found in the discourses of the participants that there was interference in the therapeutic alliance in the face-to-face treatment as a result of the use of these resources. Similar to the findings of this study, in a systematic review, Sucala et al. (2012) conclude that it is possible to develop an effective therapeutic alliance using the Internet, including online treatments, where there is no non-verbal communication. In this sense, the importance of establishing a positive bond at the beginning of the psychotherapeutic process becomes important so that the patient continues with the psychological treatment, either face-to-face or through the technological resources.

Regarding the identification of the psychic weaknesses of the patients, it was observed that the therapists could use the information available in the ICTs to complement the face-to-face process and the dynamic understanding of their patient. This study finding contrasts with the psychoanalytic literature, since this addresses the importance of the face-to-face relationship for the management of aspects related to the psychotherapeutic treatment (Eizirik, Aguiar, $\&$ Schestatsky, 2005). As a relatively new topic with this approach, several authors have contributed to reduce the controversy regarding the use, perceiving these resources as positive in the psychotherapeutic process (Barcellos et al., 2015, Sfoggia et al., 2014). Technological resources have the potential to become a tool allied to the professionals in their clinical practice, since they help in the complementation of the relationship between the pair and in the interventions of the therapist (Luz, 2015).

In the neutrality category, the predominant themes were linked to the concern with the personal positioning of the therapists, their exposure in the ICTs and the perception of the neutrality in the present day. In the psychoanalytic literature, Freud (1912/1996a) argued that the psychotherapist's abstinence and neutrality were essential mechanisms for achieving the goals of psychotherapy. From this perspective, the therapists' concerns about remaining neutral and reserved are based on the premises of the psychoanalytic literature itself. However, while it is important for professionals to maintain a weighted management regarding the use, restricting information and communication technologies altogether may be less neutral than using them (Barbosa et 
al., 2013; Luz, 2015). Therefore, Sfoggia et al. (2014) argue that the way the therapist and patient use these technologies is what will impact the treatment and not the technology itself. Possibly, the negative influence on neutrality may also be related to the fact that the participating therapists linked the term neutrality to abstinence, with these concepts having differences of understanding.

For Falcão (2007), neutrality is based on a neutral analyst in relation to his convictions, his ideals and the transferential manifestations. Thus, it would not be in the hands of the therapist to impose desires and choices on the patient (Meissner, 1998). On the other hand, abstinence is related to substitutive gratifications, so that the patient encounters them as little as possible during the treatment (Falcão, 2007). However, Freud himself, in some situations, ended up gratifying his patients, when he praised them for express reports, for example (Zamfirescu, 2013). Zamfirescu (2013) argues that depriving the patient of all gratifications would be unbearable. In this sense, it can be thought that using the technologies with patients would be a form, even if only initial, of welcoming the patient so that later this use can be directed toward another destination, such as an increase in the frequency of the sessions or an interpretation of their use. In addition, it seems that the technology may not directly affect the therapist's neutrality, but, rather, the abstinence of the therapist, with the care of the professional being necessary so that the ICTs are not a path of substitutive gratification.

In relation to the perception of neutrality in the present day, it is notable that technologies are increasingly present in the personal and professional lives of psychotherapists (Hallberg, \& Lisboa, 2016). Gabbard (2012) considers the loss of anonymity as one of the great changes for psychodynamic work. Therefore, primarily, Freud can be referred to when he wrote that some permission must be given according to each patient and his/her individuality, without becoming excessive (1919/1996c), with the professional posture on the Internet being based on the recommendations of Gabbard et al. (2011). These authors recommend that professionals activate privacy settings, monitor personal information available on the Internet, and do not search for their patients on the data networks. These rules may help professionals cope with the possible loss of a neutral posture, although this may not occur due to the use of the technologies.

Regarding the therapeutic setting, results were found related to the therapeutic contract, the extra-setting situations and the technological resources as a third party in the therapeutic setting. It was perceived in the interviews that the use and management by the psychotherapists were related to the specific issues of the work contract and that they were part of the framework, even if not previously agreed upon. Barcellos et al. (2015) argue that these situations, although not initially agreed upon by the pair, can be comprehended as part of the analytical field, constituting a unique construct of the pair that can be used to favor the therapeutic relationship. The same authors discuss these situations as an expression of the anxieties and conflicts of patients discharged via an act (2015).

Another prism for the modifications in the setting by means of ICTs can be observed from the concept of parameters to the psychotherapy (Migone, 2013). The notion of this concept has as the premise the explanation of those situations that may transgress the framework. In order to be included, the psychotherapist must be sure that he or she will be able to control them, to assess whether they will harm the setting and whether they will be able to return to the original combinations with the patient (Zimerman, 1999). Therefore, the use of these technologies can be proposed as a form of initial concession so that it is a channel of expression for the patient, in order to propose it as a parameter to the technique. For Sfoggia et al. (2014), the external setting may become flexible, provided that the internal setting of the therapist is preserved.

Regarding technological resources as a third party in the therapeutic setting, Stadter (2013) comprehended these new technological objects as an e-third (electronic third party), which enters the sessions as a transition element enters the life of a child, with the intention of 
becoming independent of the first interpersonal relationships. This electronic third party would aid in the establishment of these relationships, although he also problematized that these ICTs could become resources of technological dependency (Stadter, 2013). However, technological resources increase the possibility that the patient can easily express content that is still difficult or intolerable to present otherwise, such as in person for example (Migone, 2013). The therapist's role would be to capture these communicative actions and be able to interpret this situation so that they could be worked on in the face-to-face context and not only resolved through the technological resources.

Finally, the results of the study regarding transference are related to technological resources as representative of the desires of the patients and to the manifestation of transference in the information and communication technological resources. With these resources, the transference finds a new space for expression (Kowacs, 2014), reducing the time span related to solitude or exclusion and allowing the patient to effectively enter the life of the therapist (Kowacs, 2014), denouncing his/her affective needs. In this study, the majority of the therapists believed that the manifestation of transference occurs through information and communication technologies. Although there is still no consensus in the literature regarding the presence or absence of transference in ICTs (Carlino, 2011; Garcia, 2011; Kohn, \& Roth, 2012; Scharff, 2013)

For Garcia (2011), transference would only happen if there was the real presence of the pair in the session. Kohn and Roth (2012) proposed that this occurs even in the use of these technological resources. Through the interviews conducted in this study, the therapists believed that there is transference through ICTs. Corroborating this perspective, Scharff (2013) argues that transferential and countertransferential elements are present in the use of these technologies. For the author, free association and transference are not compromised by technological resources. Although the discussions of these authors are related to online psychotherapy sessions, the use of ICTs in psychotherapeutic consultations that have face-to-face meetings can be understood as similar to non-face-to-face (online) contact, since there is no physical presence of the pair in the use of these technologies.

However, the reflection should not be restricted to the presentation or not of an element of the psychoanalytic technique, but rather to the perception of these manifestations as a complex phenomenon. Barbosa et al. (2013), in a metaphorical way, wrote that it is necessary to "throw the baby out and keep the rest of the dirty bath water" (p. 67). The implicit idea is not only to look at the technology, but at the results it brings, as they can represent the unique desires, needs and behaviors of the patient. Therefore, it is believed to be interesting to reflect on the use of ICTs, as long as it is not a technological perversion to contribute as a space of transferential communication of the patient. However, it is also important to emphasize the need for the absence of the therapist in the patient's life between one session and another so that the patient can subjectivate. In this sense, it is important that the therapist can remain available and continent, however, can also provide limits and a certain lack of gratification. It will be in this transferential game that new analytic constructions will be fertilized (Barbosa et al., 2013).

\section{Conclusion}

This article aims to comprehend how psychodynamic psychotherapists perceive the impact on the face-to-face psychoanalytic psychotherapeutic technique in relation to the use of information and communication technological resources with their patients. The length of clinical experience and professional training seem to indicate no difference in the perception of the impacts on the psychoanalytic technique. The results show that the influences were related to adherence to the treatment, to the identification of the psychic weaknesses of the patient, to the positioning and exposure of the therapist, to the perception of neutrality, to the therapeutic contract, to extra-setting situations, to technological resources as a third party in the therapeutic setting as representatives of the patients' desires 
and to the manifestation of transference in the information and communication technological resources.

If we start from the premise mentioned in the Freudian work that the psychic functioning of subjects is governed by the unconscious and that there are no temporal or spatial rules for this, since it can manifest itself in different forms, we can reflect that information and communication technologies serve as a channel of communication of unconscious contents of the patient. It is important to emphasize that we still discuss the subject in a cautious way, because this is relatively new in the psychodynamic professional practice. However, as seen in the results of this study, information and communication technologies can be aids in the psychic comprehension of the patient, as well as in the psychoanalytic process. To deny technology might be more damaging to our work than to look at it with parsimony, accept its inclusion and work on it with each patient, after all, there is no way to generalize its use.

It should be noted that we are part of a society that is in constant transformation. With this, we must remember that the psychoanalytic study takes into consideration social variables of the individual, for example, the transmission of values between the generations and the context inserted.

It is believed to be important to discuss the theme in the training centers that teach psychoanalytic psychotherapy to comprehend what affects this use mobilizes in the therapist, as well as to instrumentalize the professionals for the appropriate use of the technique. In addition, whenever necessary, the therapist should seek supervision of clinical cases to deepen the situations experienced in the clinic.

Regarding the limitations of the study, the restricted use of the contractual agreements by the professionals regarding the ICTs can still be seen. Possibly, if the management was better established among the participants, the results could be deepened in relation to the technique.

In relation to future directions, quantitative research is needed with Brazilian samples related to how the professionals of the country perceive the impacts on the psychoanalytic technique and how they manage them, both with psychodynamic psychotherapists and analysts. In addition, it is necessary to analyze the use of information and communication technologies in single case studies delineated in studies of process and results in psychotherapy. Finally, an axis of investigation that needs attention is related to how the institutions that provide undergraduate psychology courses and postgraduate psychoanalysis courses have discussed the subject with their students. Psychotherapy and technologies prove to be promising themes in the area of psychology, since they increase the possibilities of intervention with individuals and collectivities.

\section{Authors' Contributions}

Substantial contribution in the concept and design of the study: Luan Paris Feijó; Silvia Pereira da Cruz Benetti

Contribution to data collection: Luan Paris Feijó

Contribution to data analysis and interpretation: Luan Paris Feijó e Nathália Bohn da Silva

Contribution to manuscript preparation: Luan Paris Feijó

Contribution to critical revision, adding intelectual content: Luan Paris Feijó; Silvia Pereira da Cruz Benetti

\section{Conflicts of interest}

The authors declare that they have no conflict of interest related to the publication of this manuscript.

\section{References}

Barbosa, A. M. F. D. C., Furtado, A. M., Franco, A. L. D. M., Berino, C. G. D. S., Pereira, C. R., Arreguy, M. E., \& Barros, M. J. D. (2013). As novas tecnologias de comunicação: Questões para a clínica psicanalítica. Cadernos de Psicanálise (Rio de Janeiro), 35(29), 59-75. Retrieved from http://pepsic.bvsalud.org/scielo.php?script $=$ sci arttext\&pid=S1413-62952013000200004\&lng= pt\&tlng $=\mathrm{pt}$ 
Barcellos, E. D., Campezatto, P. V. M., Geremia, L., Vieira, M. F., Cavalheiro, R., \& Klarmann, R. P. (2015). As novas formas de comunicação e suas possíveis influências sobre o setting e o campo psicoterápico. Psicoterapia Psicanalítica, 17, 39-51.

Barnett, J. E. (2011). Utilizing technological innovations to enhance psychotherapy supervision, training, and outcomes. Psychotherapy, 48(2), 103. doi: http://dx.doi.org/10.1037/a0023381

Braun, V., \& Clarke, V. (2006). Using thematic analysis in psychology. Qualitative Research in Psychology, 3(2), 77-101. Retrieved from http://www.tandfonline.com/doi/ abs/10.1191/1478088706qp063oa

Breakwell, G. M., Hammond, S., Five-Schaw, C., \& Smith, J. A. (2010). Métodos de pesquisa em psicologia (F. R. Elizalde, Trans., $3^{\text {rd }}$ ed.). Porto Alegre, RS: Artmed.

Bunge, E., López, P., Mandil, J., Gomar, M., \& Borgialli, R. (2009). Actitudes de los terapeutas argentinos Hacia La incorporación de nuevas tecnologías en psicoterapia. Revista Argentina de Clínica Psicológica, 18(3), 209-216. Retrieved from http://www.redalyc.org/articulo. oa? id=281921775002

Carlino, R. (2011). Distance psychoanalysis: The theory and practice of using communication technology in the clinic (J. Nuss, Trans.) London: Karnac.

Conselho Federal de Psicologia. (2012). Resolução CFP $n^{\circ}$ 011/ 2012. Regulamenta os serviços psicológicos realizados por meios tecnológicos de comunicação a distância, o atendimento psicoterapêutico em caráter experimental e revoga a Resolução CFP N. ${ }^{\circ}$ 12/2005. Brasília, DF: Author

Crestana, T. (2015). Novas abordagens terapêuticasterapias on-line. Revista Brasileira de Psicoterapia, 17(2), 35-43. Retrieved from http://rbp. celg.org.br/detalhe_artigo.asp?id=176

Distéfano, M. J., Mongelo, M. C., O'Conor, J., \& Lamas, M. C. (2015). Psicoterapia y tecnología: implicancias y desafíos en la inserción de recursos innovadores en la práctica clínica argentina. Revista Electrónica de Psicología Iztacala, 18(4). Retrieved from http://www.revistas. unam.mx/index.php/repi/article/view/53433

Eizirik, C. L., Aguiar, R., \& Schestatsky, S. S. (2005). Psicoterapia de Orientação Analítica:
Fundamentos teóricos e clínicos. Porto Alegre, RS: Artmed.

Falcão, L. (2007). Neutralidade e abstinência ontem e hoje. Revista de Psicanálise da SPPA, 14(2), 289-303.

Feijó, L. P., Silva, N. B., \& da Cruz Benetti, S. P. (2018). Experiência e Formação Profissional de Psicoterapeutas Psicanalíticos na Utilização das Tecnologias de Informação e Comunicação. Psicologia: Ciência e Profissão, 38(2), 249-261. http://dx.doi.org/10.1590/1982-3703003032017

Fontanella, B. J. B., Ricas, J., \& Turato, E. R. (2008). Amostragem por saturação em pesquisas qualitativas em saúde: Contribuições teóricas. Cadernos de Saúde Pública, 24(1), 17-27. Retrieved from https://dx.doi.org/10.1590/ S0102-311X2008000100003

Freud. S. (1996a). Recomendações aos jovens médicos que exercem a psicanálise. In Edição Standard Brasileira das Obras Psicológicas Completas de Sigmund Freud. Rio de Janeiro: Imago. (Original work published in 1912)

Freud, S. (1996b). Recordar, repetir e elaborar. In: In: Edição Standard Brasileira das Obras Psicológicas Completas de Sigmund Freud. Rio de Janeiro, RJ: Imago. (Original work published in 1914)

Freud, S. (1996c). Linhas de progresso na terapia psicanalítica. In Edição Standard Brasileira das Obras Psicológicas Completas de Sigmund Freud. Rio de Janeiro, RJ: Imago. (Original work published in 1919)

Freud, S. (1996d). Além do princípio do prazer. In Edição Standard Brasileira das Obras Psicológicas Completas de Sigmund Freud. Rio de Janeiro, RJ: Imago. (Original work published in 1920)

Gabbard, G. O. (2012, November 17). Psychoanalysis in the era of cyberspace. Interview with Glen O. Gabbard/Interviewer: Sabrina Di Cioccio. In Funzione Gamma: journal on line di psicologia di grupo, Conferência promovida pela APA e D. Winnicott Centre, Departamento of Pediatry and Infant Neuropsychitary de Sapienza. Universidade de Roma. Retrieved from http://www. funzionegamma.it/psychoanalysis-in-the-eraof-cyberspace-interview-with-glen-o-gabbard/

Gabbard, G. O. (2015). Intervenções terapêuticas. O que o terapeuta diz e faz? In G. O. Gabbard, Psi- 
coterapia psicodinâmica de longo prazo. Texto Básico. Porto Alegre, RS: Artmed.

Gabbard, G. O., Kassaw, K. A., \& Perez-Garcia, G. (2011). Professional boundaries in the era of the Internet. Academic Psychiatry, 35(3), 168-174. doi: 10.1176/appi.ap.35.3.168

Garcia, J. (2011). The training of psychoanalysts in Latin American countries without IPA institutions: Antecedents, experiences and problems encountered. International Journal of Psychoanalysis, 92, 715-731. doi: 10.1111/j.17458315.2011.00464.x

Gerhardt, T. E., \& Silveira, D. T. (2009). Métodos de Pesquisa. Porto Alegre, RS: Editora da Universidade Federal do Rio Grande do Sul.

Hallberg, S. C. M. (2015). Percepção e uso de tecnologias da informação e comunicação por psicoterapeutas (Master thesis, Pontifícia Universidade Católica do Rio Grande do Sul, Porto Alegre, RS, Brazil).

Hallberg, S. C. M., \& Lisboa, C. S. D. M. (2016). Percepção e uso de tecnologias da informação e comunicação por psicoterapeutas. Temas em Psicologia, 24(4), 1297-1309. doi: https:// dx.doi.org/10.9788/TP2016.4-06

Instituto Brasileiro de Geografia e Estatística. (2013). Pesquisa nacional por amostra de domicilios: Acesso à internet e à televisão e posse de telefone móvel celular para uso pessoal. Retrieved from http://biblioteca.ibge.gov.br/visualizacao/livros/ liv93373.pdf

Kohn, N. V., \& Roth, J. D. (2012). The blank screen of cyberspace. Psychoanalytic Inquiry, 32(5), 426-437. doi: http://dx.doi.org/10.1080/073516 90.2012.703565

Kowacs, C. (2014). Prática psicanalítica, tecnologia e hipermodernidade. Revista de Psicanálise da SPPA, 21(3), 629. Retrieved from http://revista.sppa.org.br/index.php/RPdaSPPA/article/ view/135/230

Luz, A. B. (2015). Oi. Q horas mesmo ficou nossa sessão? TKS. Revista Brasileira de Psicanálise, 49(1), 165-175.

Machado, D. B., Laskoski, P. B., Severo, C. T., Bassols, A. M., Sfoggia, A., Kowacs, C., ...Eizirik, C. L. (2016). A psychodynamic perspective on a systematic review of Online Psychotherapy for Adults. British Journal of Psychotherapy, 32(1), 79-108. doi: http://onlinelibrary.wiley.com/ doi/10.1111/bjp.12204/abstract
Meissner, W. W. (1998). Neutrality, abstinence, and the therapeutic alliance. Journal of the American Psychoanalytic Association, 46(4), 1089-1128. Retrieved from https://www.ncbi.nlm.nih.gov/ pubmed/9934659

Migone, P. (2013). Psychoanalysis on the Internet: A discussion of its theoretical implications for both online and offline therapeutic technique. Psychoanalytic Psychology, 30(2), 281. doi: http:// dx.doi.org/10.1037/a0031507

Miró, J. (2007). Psicoterapia y nuevas tecnologías. Cuadernos de Medicina Psicosomática y Psiquiatría de Enlace, 81, 15-20. Retrieved from http://in3.uoc.edu/opencms_in3/ export/sites/in3/webs/grups_de_recerca/psinet/_ resources/documents/Miro.pdf

National Health Council. (2016). Resolução 510 de 07 de abril de 2016. Dispõe sobre as normas aplicáveis a pesquisas em Ciências Humanas e Sociais. Brasília, DF: Presidência da República.

Neves, R. C., \& Silva, M. R. (2014). Reflexões sobre a comunicação por SMS e o processo psicoterápico. Anais do Salão de Iniciação Científica da UFRGS. Porto Alegre, RS. Retrieved from http://www.lume.ufrgs.br/handle/10183/113817

Oliveira, N. H., \& Benetti, S. P. C. (2015). Aliança terapêutica: Estabelecimento, manutenção e rupturas da relação. Arquivos Brasileiros de Psicologia, 67(3), 125-138. Retrieved from http://pepsic.bvsalud.org/scielo.php?script=sci arttext\&pid=S1809-52672015000300010\&lng= pt\&tlng=pt

Pieta, M. A. M., \& Gomes, W. B. (2014). Online therapy: viable or unviable?. Psicologia: Ciência e Profissão, 34(1), 18-31. doi: https://dx.doi. org/10.1590/S1414-98932014000100003

Pieta, M. A. M., Siegmund, G., Gomes, W. B., \& Gauer, G. (2015). Desenvolvimento de protocolos para acompanhamento de psicoterapia pela Internet. Contextos Clínicos, 8(2), 128140. Retrieved from http://revistas.unisinos. br/index.php/contextosclinicos/article/view/ ctc. 2015.82 .02

Pires, A. C. J. (2015). Sobre os "tratamentos à distância” em psicoterapia de orientação analítica. Revista Brasileira de Psicoterapia, 17(2), 1121. Retrieved from http://rbp.celg.org.br/detalhe_artigo.asp?id=174

Scharff, J. S. (2013). Psychoanalysis Online: Mental Health, Teletherapy, and Training. London: Karnac. 
Sfoggia, A., Kowacs, C., Gastaud, M. B., Laskoski, P. B., Bassols, A. M., Severo, C. T., Machado, D., ...Eizirik, C. L. (2014). Therapeutic relationship on the web: To face or not to face?. Trends in Psychiatry and Psychotherapy, 36(1), 3-10. Retrieved from http://www.scielo.br/ scielo.php?script $=$ sci_arttext\&pid $=\mathrm{S} 2237$ $60892014000100003 \& \operatorname{lng}=$ en\&tlng=en

Stadter, M. (2013). The influence of social media and the communications technology on self and relationships. In J. S. Scharff (Ed.), Psychoanalysis online: Mental health, teletherapy and training (pp. 3-14). London: Karnac Books.

Sucala, M., Schnur, J. B., Constantino, M. J., Miller, S. J., Brackman, E. H., \& Montgomery, G. H. (2012). The Therapeutic Relationship in E-Therapy for Mental Health: A Systematic Review. Journal of Medical Internet Research, 14(4), e110. Retrieved from http://www. jmir.org/2012/4/e110/

Tong, A., Sainsbury, P., \& Craig, J. (2007). Consolidated criteria for reporting qualitative research (COREQ): A 32-item checklist for interviews and focus groups. International Journal for Quality in Health Care, 19(6), 349-357. doi: 10.1093/intqho/mzm042
Zamfirescu, V. D. (2013). Freud between the clinical practice and the theory of technique. Romanian Journal of Psychoanalysis/Revue Roumain de Psychanalyse, 6(1).

Zilberstein, K. (2015). Technology, relationships and culture: Clinical and theoretical implications. Clinical Social Work Journal, 43(2), 151158. Retrieved from https://link.springer.com/ article/10.1007/s10615-013-0461-2

Zimerman, D. E. (1999). Fundamentos psicanaliticos: Teoria, técnica, clínica - Uma abordagem didática. Porto Alegre, RS: Artmed.
Received: $28 / 07 / 2017$

$1^{\text {st }}$ revision: $17 / 10 / 2017$

Accepted: 17/10/2017

(c) BY The Author(s), 2018. Open Access. This article is distributed under the terms of the Creative Commons Attribution 4.0 International License (http://creativecommons.org/licenses/by/4.0/), which permits unrestricted use, distribution, and reproduction in any medium, provided you give appropriate credit to the original author(s) and the source, provide a link to the Creative Commons license, and indicate if changes were made. 